Council of Europe

- Conservation of Wildlife and Natural Habitats IUCN

- Antarctica and the Southern Ocean

Consultative Parties

- Conservation of Antarctic Marine Living Resources

UN Economic Commission for Europe

- Prevention and Control of Water Pollution, including Transboundary Pollution

- Long-range Transboundary Air Pollution (possible draft convention)

- Low and Non-waste Technology and Reutilization and Recycling of Wastes (agreed elements for draft declaration of intent)

- Inter-State Conferences

- High-Level Meeting

International Conference on Chlorofluoromethanes - Recommendations

Quelques Articles de la Nouvelle Constitution Espagnole (Some Articles of the New Spanish Constitution)

UN 33rd General Assembly

- UN Conference on New and Renewable Sources of Energy

- Third UN Conference on the Law of the Sea

- Cooperation in the Field of the Environment Concerning Natural Resources Shared by Two or More States

- Report of the Governing Council of UNEP

CITES: Second Meeting

- Financing of the Secretariat

-.. Speech of Mostafa K. Tolba

European Community

- Note Verbale on Controlling Toxic Substances

UNEP

- Programme Policy and Implementation

- Environment and Develpment

- Farthwatch: Monitoring of Transboundary Transmission of Air Pollutants

- Environmental Assessment

- Intcrnational Referral System (Infoterra)
- Health of People and of the Environment

- Convention on International Trade in Endangered Species of Wild Fauna and Flora

- Establishment of a Trust Fund for the Convention on International Trade in Endangered Species of Wild,Fauna and Flora

58 - Implementation of the Plan of Action to combat Desertification in the African Region

- Implementation of the Plan of Action to Combat Desertifica tion with Special Reference to the Sudano-Sahelian Region

- Special Account to Finance the Implementation of the Plan of Action to Combat Desertification

- Establishment of a Trust Fund for the Protection of the Mediterranean Sea Against Pollution

- Cost-Benefit Analysis

- Working Group of Experts on Environmental Law

- Programme Matters

- Management of the Environment Fund

OECD

- Assessment of Projects with Significant Impact on the Environment

- Anticipatory Environmental Policies

- State of the Environment

UNCTAD

- Common Fund

Migratory Species Convention

- The Bonn Convention on the Conservation of Migratory Species of Wild Animals

Perou

- Constitution Politique

NATO

110 - Impact of Advanced Technology on Ocean Management

Germany, Federal Republic

- Points on the Economic Justification of the Federal Law on Protection Against Immissions

European Parliament

- Resolution on I) the Best Means of Preventing Accidents to Shipping and Consequential Marine and Coastal Pollution and II) Shipping Regulations
155

157

157

\title{
Author Index of Volume 5
}

Adede, A. O., 66

Bennett, Graham, 93, 190

Bridgeman, James C., 162

Bundi, U., 27

de Klemm, Cyrille, 89

Di Giovine, Giuseppe, 38

Dupuy, Pierre, 175

Forster, Malcolm, 170
Ginjaar, Leendert, 41

Gospodarek, Mary, 100

Hannequart, Jean-Pierre, 37

Kimball, Lee, 34, 128, 162

Kiss, Alexandre-Charles, 6, 79

Koester, Veit, 178

MacNeill, J. W., 145

Malanczuk, Peter, 20, 179

Mauch, S., 27
Moltke, Konrad von, 92, 140

Müller, Frank G., 13

Remond-Gouilloud, Martine, 194

Rest, Alfred, 85

Schneider, Adolf R. H., 128, 162

Smets, Henri, 143, 175

Van Beek, Drake, 2, 9

van Heijnsbergen, P., 11

Vogel, Howard H., 186 